\title{
The Biological Roots of Private Ownership?
}

\author{
Marina Vančatová ${ }^{1}$ - Václav Vančata ${ }^{2,3}$ \\ 1 Zelení Poutníci, o.s, Loučimská 1052, 10200 Praha 10 \\ 2 Department of Anthropology, Faculty of Science, Masaryk University, Kotlářská 267/2, 61137 Brno \\ 3 Department of Biology and Environmental Studies, Faculty of Education, Charles University, M. Rettigové 4, 11639 Praha 1
}

Received 21 ${ }^{\text {st }}$ September 2017; accepted $13^{\text {th }}$ November 2017

\section{BIOLOGICKÉ KOŘENY SOUKROMÉHO VLASTNICTVÍ?}

\begin{abstract}
ABSTRAKT Formy vlastnictví některých objektů a jejich význam mohou být velmi variabilní, a to jak v různých lidských společnostech, tak i u ostatních primátů, zejména u velkých lidoopů. Sociální organizace lidoopů se liší v mnoha ohledech od většiny lidských společností. Naše studie lidoopů v zajetí by nám mohla pomoci vyřešit, zda mají lidoopi tendenci vlastnit libovolný objekt, nebo ne. Pozorování byla provedena ve dvou zoologických zahradách v České republice - Zoo Dvưr Králové a v Zoo Praha. Všechna popsaná pozorování prokázala skutečnost, že tendence k vlastnění objektů nesouvisejících s potravou existuje nezávisle na sobě u šimpanzů, goril a orangutanů. Velmi podobné údaje pro lidoopy chované v zajetí i pro divoce žijící lidoopy potvrzují, že tento typ chování není náhodný. To bylo opakovaně prokázáno u všech tří pozorovaných druhů lidoopů. Naše studie prokázaly, že existuje možnost interpretovat dlouhodobé individuální vlastnictví objektů během nepotravních aktivit u lidoopů i jako způsob osobního vlastnění těchto objektů.
\end{abstract}

KLÍČOVÁ SLOVA evoluce; gorila; orangutan; šimpanz; instinkt vlastnictví; zoo

ABSTRACT Objects, forms of ownership, and their meanings are variable among different human societies, as well as in other primates, especially in the great apes. The social organization of apes differs in many respects from most human societies. This study of the pongids in captivity will help researchers to resolve the question of whether or not apes have object ownership. For our research, observations were carried out at two zoos in the Czech Republic: Dvůr Králové Zoo and the Prague Zoo. All the described observations proved that a tendency to own non-feeding objects exists among chimpanzees, gorillas, and orangutans in captivity. Similar data in both captivity and in the wild has confirmed that this type of behavior is not random in the great apes, but is deliberate. In fact, it has been repeatedly observed in all three species of pongids. This study has shown that apes possessed objects during non-feeding activities, which suggests a form of object ownership.

KEY WORDS evolution; gorilla; orangutan; chimpanzee; property instinct; zoo

\section{INTRODUCTION}

Humans and the great apes are very closely related, both in terms of genetics and behavior. However, some features of behavior, such as religiosity and ownership of complex objects, are perhaps common only in modern humans (Homo sapiens sapiens). The problem scientists struggle with is how to define ownership in its most rudimentary form as is observed in the oldest surviving cultural traditions of the Bushman in Africa, the Quechua of South America, the Sepik peoples of Papua New Guinea, and the Aborigines of Australia. Forms of ownership of some objects and their meanings are variable
(Barnard 2007; 2011; Soukup 2015). Where did the beginning of ownership and possession of objects originate in human evolution? In addition, how does ownership and possession relate to the great apes?

The social organization of the pongids differs in many respects from most human societies (McGrew 1993; McGrew et al. 1996). With the great apes being always on the move, it is difficult to study them in the wild. The great apes do not have permanent housing; typically, the great apes do not stay in the same location or use the same nest. Chimpanzees, gorillas, and orangutans do not have a means for carrying or storing objects in the form of pockets or bags. As a result, it is 
a challenge to study ape-object ownership in the wild (Handwerk 2010). Studying the pongids in captivity will help one to resolve the uncertainty concerning social behavior in terms of object possession.

\section{METHODS AND THE PONGIDS STUDIED}

The pongids were studied in zoos in order to determine whether they were able to possess objects for at least a short period of time; observations were documented in the aforementioned two zoos in the Czech Republic. The research at the Prague Zoo focused on a group of gorillas that were studied for several years. This study focused on a two-and-ahalf year old male named Kiburi and an adult female named Bikira. At the Dvưr Králové Zoo, the researchers observed a group of four female chimpanzees that were reared in a large enclosure. In particular, the chimpanzees Babeta and Uke were the primary focus of this study. In both zoo cases, video records and photographic documentation were provided. Furthermore, the observations were done by a Focal Animal Sampling method (Altmann 1974).

\section{RESULTS}

\section{Prague Zoo:}

A group of gorillas were observed playing with a volleyball; this ball was not fully pumped and consequently this flattened ball was often used as a seat. Male gorilla Kiburi, the only infant in the gorilla group, during the observations, was witnessed spending a lot of time playing with this ball. For a long period of time, he was seen carrying the volleyball and never left the ball alone for long. Kiburi carried the volleyball with him constantly; he held this ball with either his hands or feet pressed against his backside. He never let go of this ball; even in cases where he had to climb up a rope, Kiburi would simply hold onto the ball between his legs. When he needed to climb trees, Kiburi would hold onto the volleyball with his hands or use his feet (Figure 1).

When Kiburi needed to climb, he relied on using both his hands and feet. In this case, he would place the ball in his mouth in order to allow for his hands and feet to have free range of motion. Once he stopped, Kiburi would then place the ball into a leather chair (Richterová, 2012). In the case of brachiating, he would hold onto the ball with both of his feet (Figure 2). Next, he would let the ball fall to the ground, but then he would immediately grab the ball.

Kiburi also used the volleyball during feeding activities; this ball was at times utilized as a table in order to lay his food on it. On occasions when Kuburi had to crawl, he would hold the ball with one hand, both hands, and/or use his feet. Kiburi would even possess the ball even while jumping. From the beginning of the jump he would hold it in his hands, then let go, and later pick up the ball again. When Kiburi observed the zookeepers from a wooden block, he would

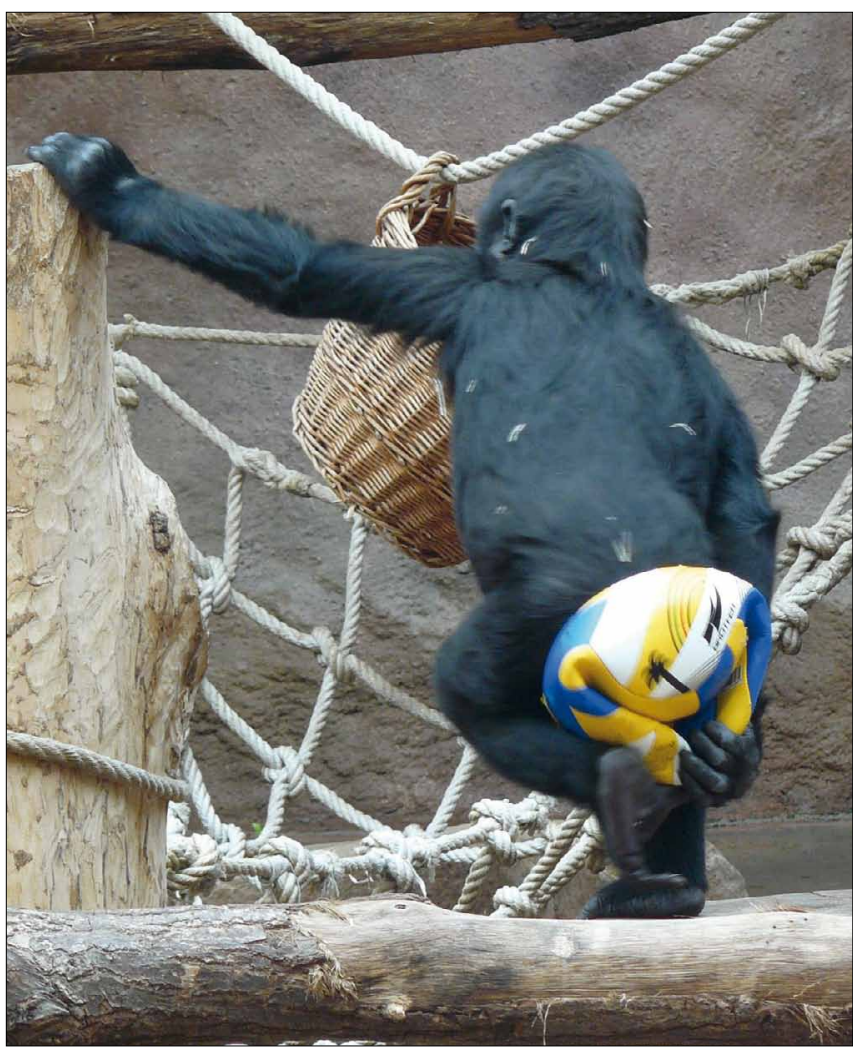

Fig. 1. Infant Gorilla, Kiburi, Using His Feet to Hold the Ball (Photo: Dana Štěpničková)

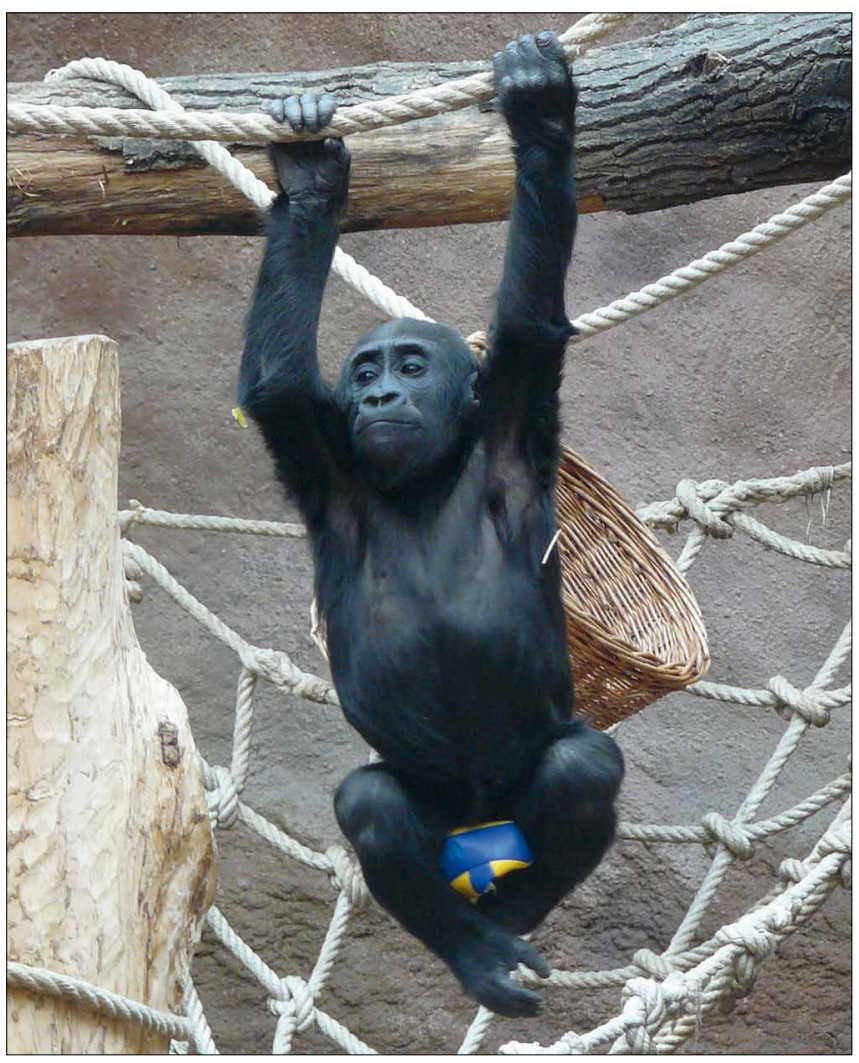

Fig. 2. Kiburi Seen Hanging With the Ball Between His Legs (Photo: Dana Štěpničková) 


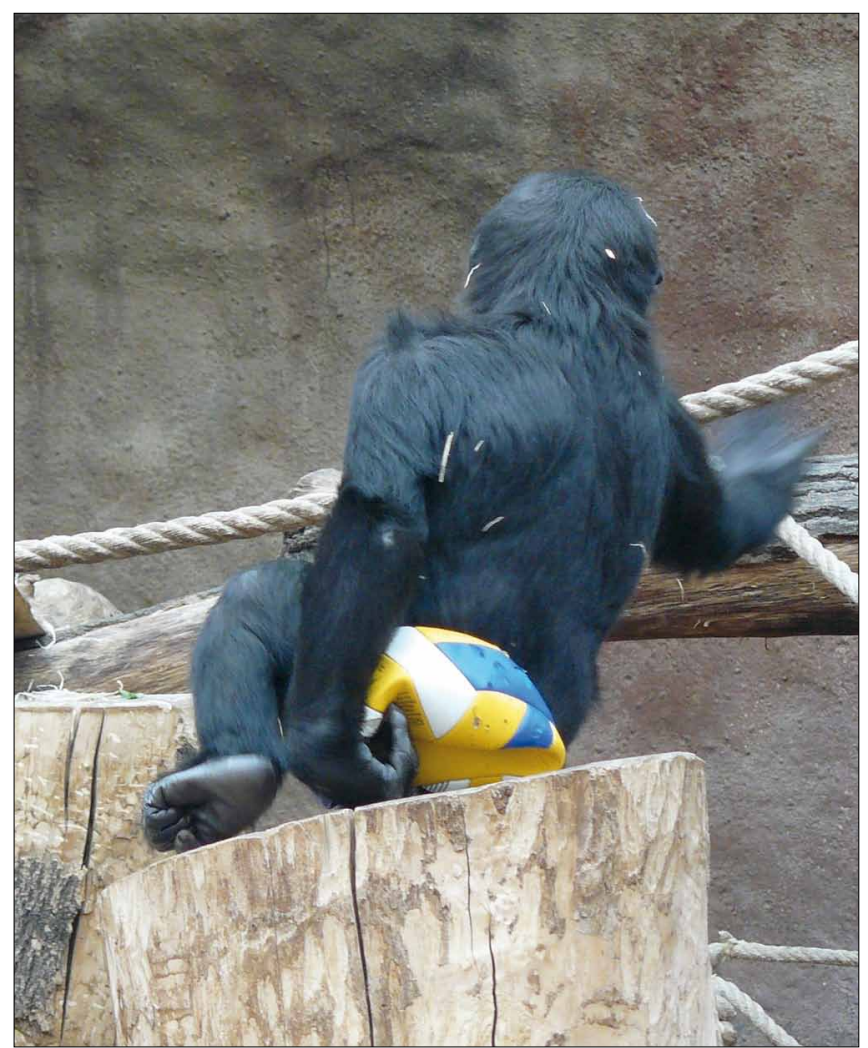

Fig. 3. Kiburi Sitting on the Ball (Photo: Dana Štepničková)

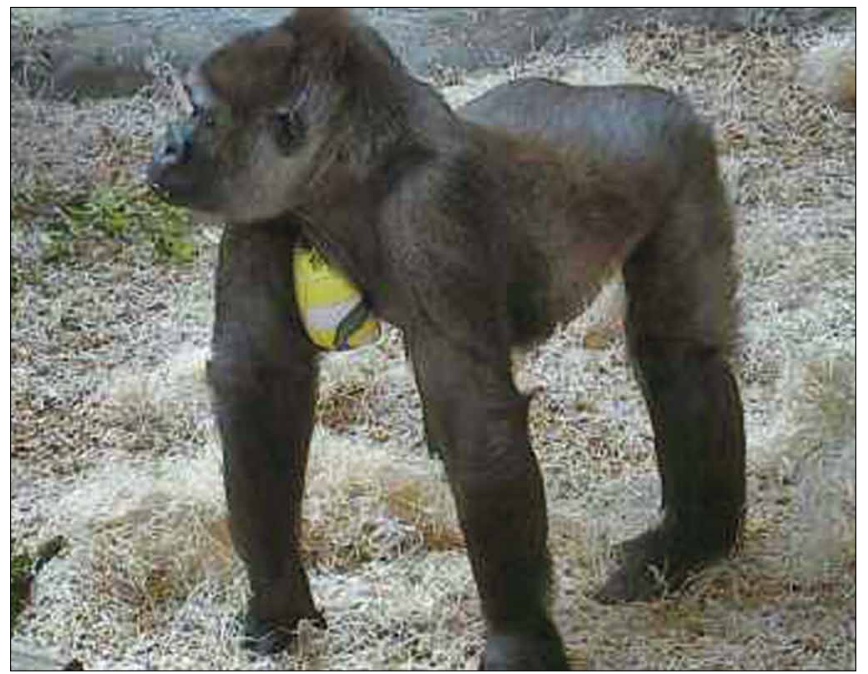

Fig. 4. Female Gorilla, Bikira, Holding The Ball in Her Armpit

bring the ball, climb onto a log, and then sit down on the ball (Figure 3 ).

Kiburi did not leave this ball for several days. Video records of this behavior have shown its continuation for over a month (Kollertová 2012 a, b.; Kondakov 2012). Kiburi preferred a partially deflated ball, because it was not round in shape and was comfortable for sitting.

If the gorilla Bikira was lying on the ground, then the ball would rest on her belly; sometimes she would hold it in her hand (Figure. 5).

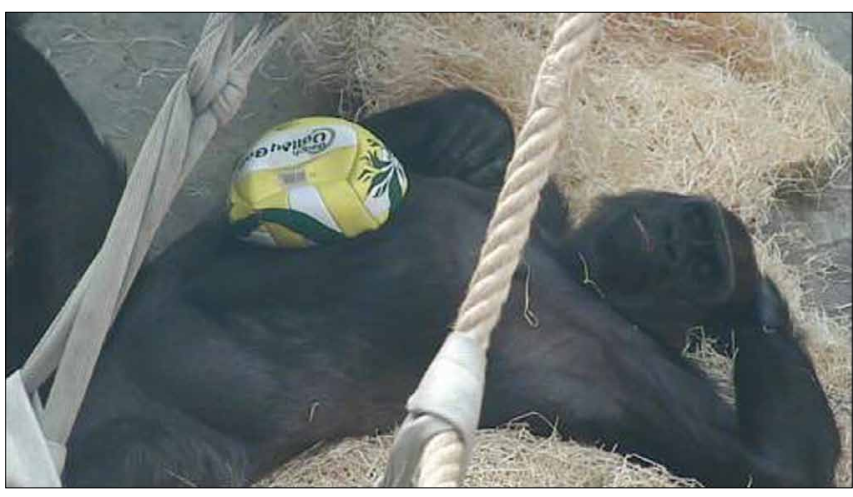

Fig. 5. Bikira Observed With the Ball Resting on Her Stomach

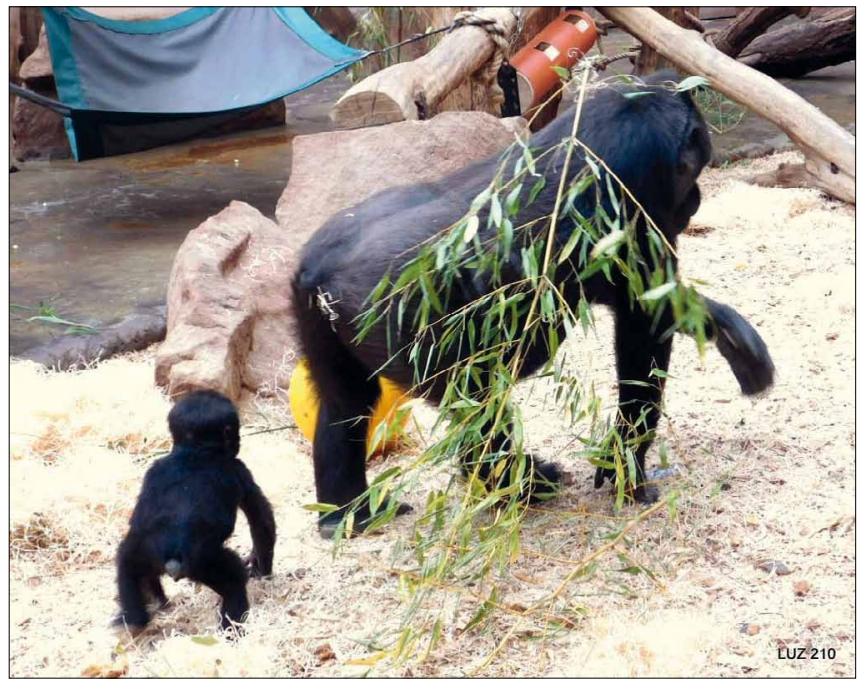

Fig. 6. Female Gorilla Carrying Branch Over Her Shoulder (Photo: Zuzana Luz)

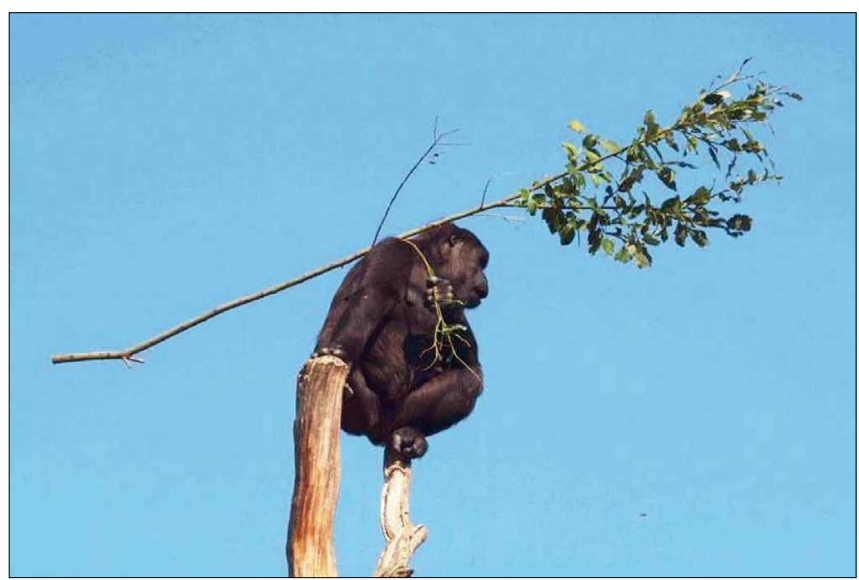

Fig. 7. Female Gorilla, Shinda, Has a Branch Resting on Her Head (Photo: Alena Stranecká)

Observations also determined that the adult females of this group would wear branches draped over their shoulders (Figure 6), on their heads (Figure 7), on their backs, or on their necks (Figure 8). 


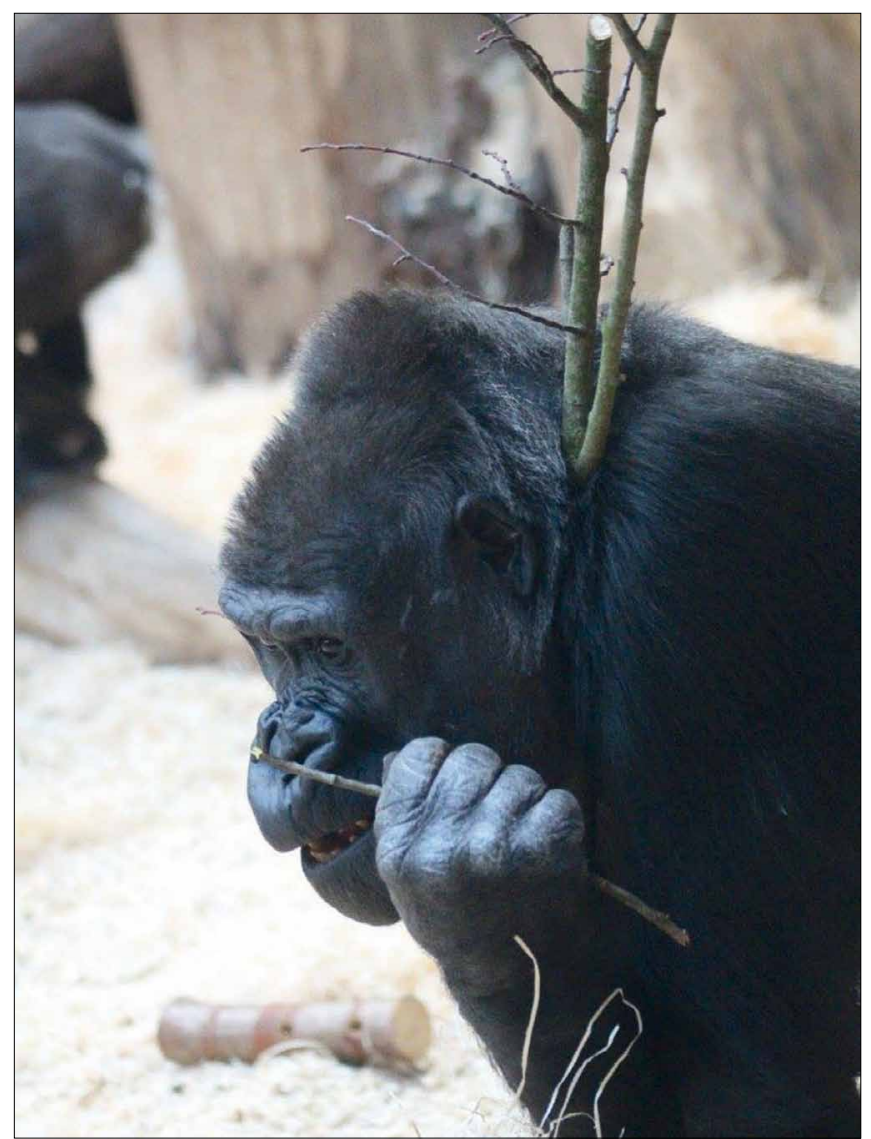

Fig. 8. Shinda Seen With a Branch in Between Her Head and Neck (Photo: Lucie Štěpničková)

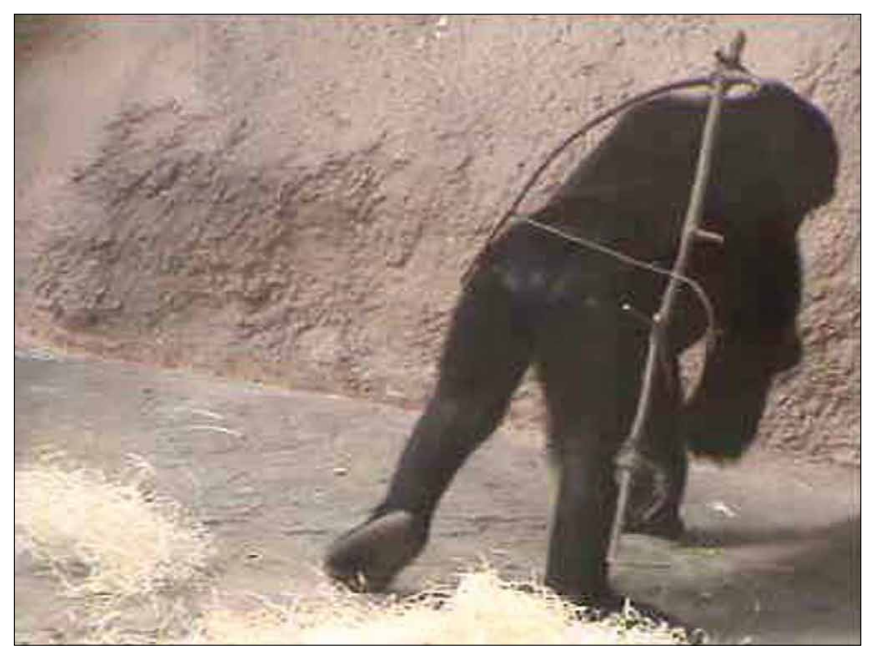

Fig. 9. Infant Gorilla, Moja, Carries a Branch Crafted in the Design of a Bow (Photo: Stanislava Štastná).

Similar behavior was also displayed in the young female Moja, who often wore a branch draped over her shoulder in the form of a bow (Figure 9). After this unique display, she was given the nickname Moja Robin Hood. In addition, Moja would also bring stones from the outdoor area to the zoo's indoor area. She would use these stones as a tool for making holes in the glass walls of the enclosure.

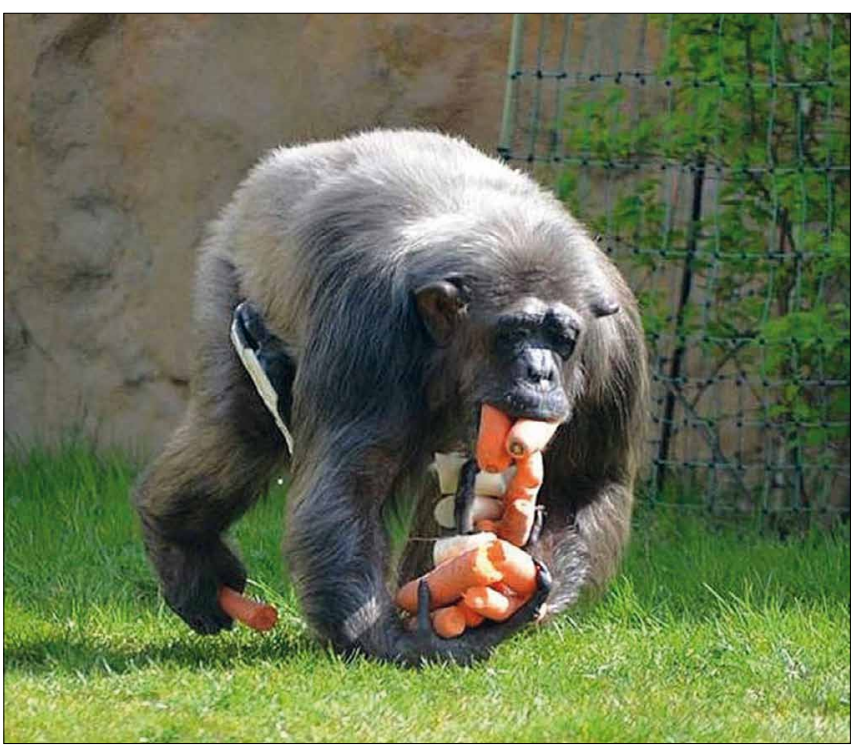

Fig. 10. Female Chimpanzee, Uke, Holding the Ball in Her Groin (Photo: Jana Myslivečková)

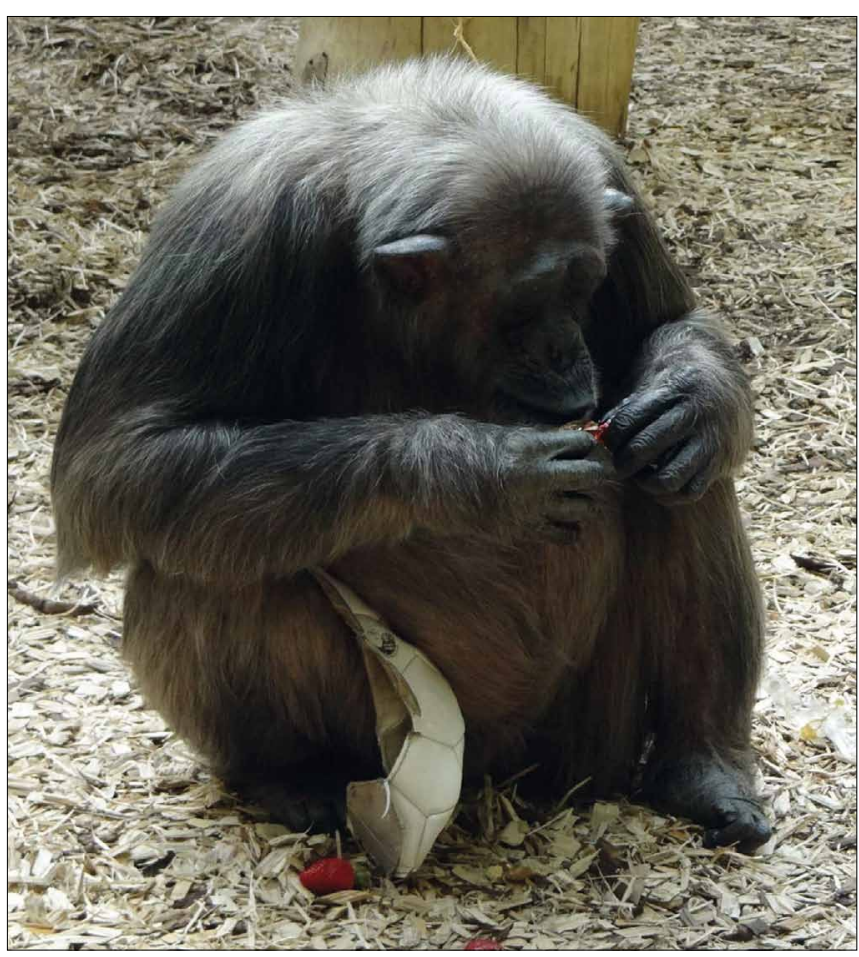

Fig. 11. Uke with the Ball in Her Groin and Sitting (Photo: Jan Kaderábek)

\section{Dvůr Králové Zoo:}

In a group of four adult female chimpanzees, it was Uke who was seen possessing a ball. It was a soccer ball, but overtime this ball was destroyed from wear and tear. Uke was later seen holding pieces of the shell from the soccer ball in her mouth. Uke had herself protectively rolled into spikes of the long flat packaging.

She was seen leaving the ball in the groin. However, she was able to move fairly quickly with it in her skin roles. If she sat, then she still kept it on her body (Figure 11). 


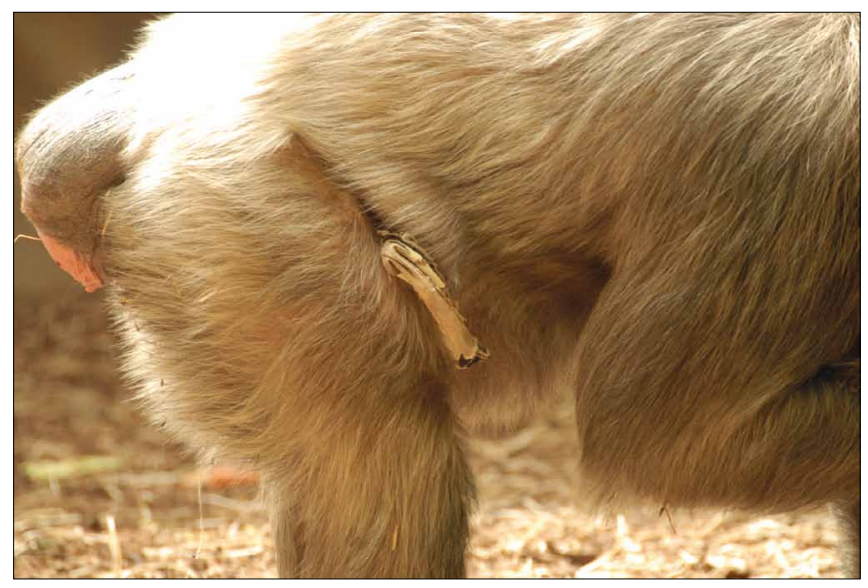

Fig. 12. Uke Observed Holding the Ball in Her Groin (Photo: Jan Kadeřábek)

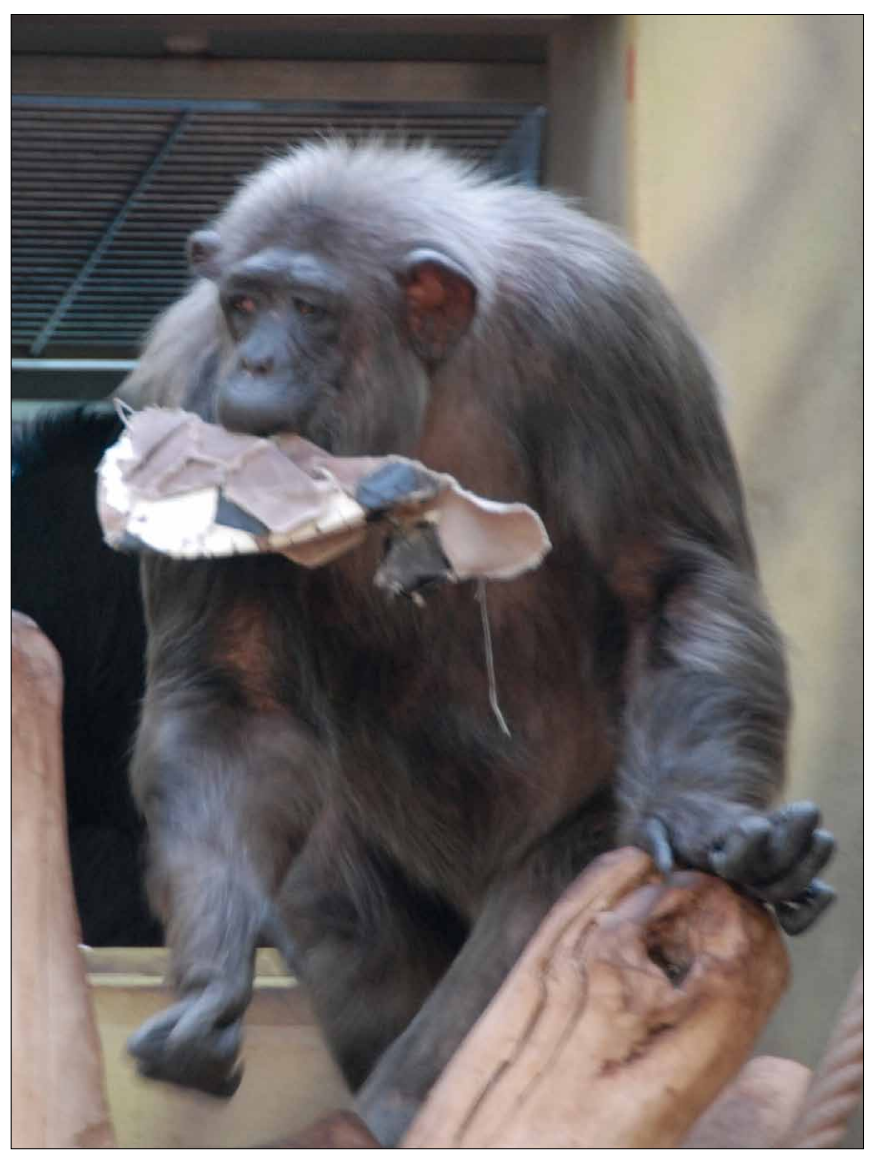

Fig. 13. Uke Seen With the Ball in Her Teeth (Photo: Jan Kadeřábek)

Uke took a piece of the shell from the soccer ball as her object of choice. She never let up on holding the ball. In the case of brachiating, Uke needed to place a piece of the ball in her mouth in order to have all of her limbs for a free range of motion (Figure 12). When climbing trees, she would carry the remains of the ball in her teeth (Figure 13).

Even when new balls were introduced and placed throughout her enclosure, Uke made no attempt to replace the shredded ball with a new one. After three years of usage, the original re- mains of the soccer ball had completely fallen apart. As a result, Uke began to carry a piece of the shell from the broken ball.

In all observed groups of gorillas and chimpanzees from various zoos, the apes often wore objects that were disposable (pieces of wood, wool, blankets, bags, etc.) on their heads and/ or shoulders. These substances were usually used by the captive apes in zoos for the construction of their nests, or used as bedding, or as a blanket.

\section{DISCUSSION}

These described types of behavior are quite rare. One of the first such ownership behaviors were described by Nadezhda Ladygina-Kohts (1935). Ladygina-Kohts compared the behavior of an infant chimpanzee to her own son. She named this type of behavior property instinct. She observed how a chimpanzee infant collected the objects in his cage. When someone wanted to take these objects, from him, this chimpanzee would become aggressive toward his provoker. The level of aggression in these cases varied in terms of the familiarity the chimpanzee had to an individual. The chimpanzee would demonstrate aggression toward people he knew and often he would attack individuals he did not know. Further evidence of apes possessing objects was supported by the primatologist Carel Van Schaik (2012); it was during his research of female orangutans in the wild that he discovered the orangutans would construct objects that appeared to be like dolls. These "leaf dolls" were then taken to bed and held during the night. In addition, Van Schaik observed the intricate detail that the orangutans demonstrated in the construction of their nests. These two unique behaviors in orangutans demonstrated their attention to detail concerning object ownership.

Similar behavior has been described also in chimpanzees (Kahlenberg - Wrangham 2009). These authors showed that chimpanzees from the Kanyawara community in Kibale National Park, Uganda, exhibit a „sticks-carrying“ behavior. Juvenile female chimpanzees used parts of branches as dolls. These branches were harder and thicker than the branches used for other types of targeting behavior. In addition, the "dolls" were carried in the chimpanzee's hands, mouth, or armpits, but more often in their groins. This same observed behavior was documented in the adult female gorillas at the Prague Zoo, as well as documented by the chimpanzee Uke at the Dvůr Králové Zoo.

Richard Wrangham observed in Uganda that wild chimpanzees placed objects on their bellies when they were lying down (video interviews from the BBC, 2016), similar to the female gorilla Bikira in the Prague Zoo. However, the transfer of objects from place to place in captivity is limited due to the size of these exposures for the great apes. Boesch and Boesch (1981) described wild chimpanzees transporting stones hundreds of meters, if there were no anvil stones in order to crack-open nuts.

It appears that keeping objects in ones groin is a common be- 


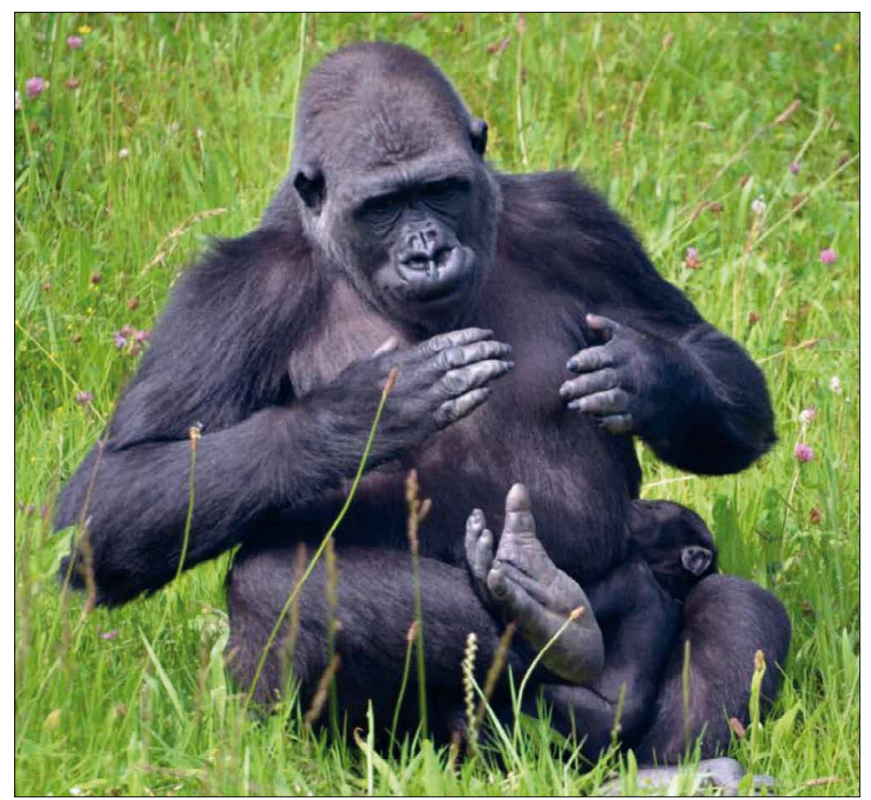

Fig. 14. Moja in the Process of Playing with her Infant (Photo: Cabarceno Zoo)

havior among the great apes. Researchers have observed it in chimpanzees (Uke, Dvůr Králové) and gorillas (Moja, Prague Zoo). A similar way of keeping branches was observed by Richard Wrangham in Uganda (personal communication). It is worth noting the female gorilla Moja, when relocated to another zoo where she gave birth to an infant, has been observed holding her infant securely in her groin (Figure 14).

All the described observations have demonstrated a tendency to own non-feeding objects among the pongids: chimpanzees, gorillas, and orangutans. Very similar data for both captive and wild apes has confirmed that this type of behavior is not random, but has been repeatedly displayed in all three observed species of the great apes.

The pattern of possessing objects is almost identical in captivity as it is in wild populations. The accumulation of nonfeeding objects, namely stones, in wild ape populations is limited primarily to the size of their territory. The accumulation of stones was described in wild chimpanzees in connection with the food behavior of cracking nuts in chimpanzees (Mercader et al. 2002). The size of indoor or outdoor areas is a limiting factor for captive apes. Remarkably, at the Furuvik Zoo in Sweden, chimpanzees collected pieces of plaster from the beginning of the day up to arrival of visitors. They would then throw these pieces of plaster at visitors for the whole rest of the day (Sample 2009).

\section{CONCLUSION}

The concept of ownership in the great apes is not identical to ownership in modern humans. The reason for this difference is that the cultural environments of these primate spe- cies differ significantly. However, our study has shown that there is a possibility of interpreting long-term individuals as possessing objects during non-feeding activities in the great apes. There are places where the accumulation of a certain objects (branches, stones, and wood) is common. Usually, these those are places where the objects are used to obtain or to process food like cracking-open nuts or gathering insects. In the case of possession, stones can be used repeatedly in order to crack open nuts by chimpanzees. However, there is no of objects documented evidence of a repeated use of these stones as tools (Kuhl et al. 2016). This behavior is likely to be merely a ritual in chimpanzees, but not the possession.

\section{ACKNOWLEDGMENTS}

The authors wish to thank to many colleagues and zoo-keepers Jana Myslivečková, Marek Ždánský. The research was partially supported by Progress funding (PRVOUK P15). Special thanks are due to authors of photos and video: Cabarceno Zoo, Jan Kaderábek, Iveta Kollertová, Sergey Kondakov, Zuzana Luz, Jana Myslivečková, Dana Richterová, Alena Stranecká, Stanislava Štastná, Dana Štěpničková, Lucie Štěpničková. Many thanks are due to an anonymous reviewer greatly helped to improve our paper also by excellent linguistic revision of the paper.

\section{REFERENCES}

Altmann, Jeanne (1974): Observational Study of Behavior: Sampling Methods. In: Behaviour, 49(3-4), 227-267.

Barnard, Alan (2007): Anthropology of Bushman. London, Bloomsbury Academic.

Barnard, Alan (2011): Social Anthropology and Human Origins. New York, Cambridge University Press.

BBC Interviews with Richard Wrangham (2016) (online): http://www.bbc. com/earth/story/20160422-the-young-chimpanzees-that-play-withdolls

Boesch, Christophe et al. (2016): Chimpanzee Accumulative Stone Throwing. In: Scientific Reports, 6:22219; doi: 10.1038/srep22219.

Boesch, Christophe - Boesch, Hedwige (1981): Sex Differences in the Use of Natural Hammers by Wild Chimpanzees: A Preliminary Report. In: The Journal of Human Evolution, 10, 585-593.

Handwerk, Brian (2010): Chimp "Girls" Play With "Dolls" Too-First Wild Evidence. In: National Geographic (online): http://news.nationalgeographic.com/news/2010/09/101220-Chimpanzees-Play-Nature-Nurture-Science-Animals-Evolution

Kahlenberg, Sonya M. - Wrangham, Richard W. (2009): Sex Differences in Chimpanzees' Use of Sticks as Play Objects Resemble Those of Children. In: Current Biology, 20, R1067-R1068.

Kollertová, Iveta (2012a): Kiburek a balónek (online): http://www.youtube. com/watch? $\mathrm{v}=\mathrm{zNVdt}$ XjHiY

Kollertová, Iveta (2012b): Bez míče ani ránu. (online): https://www.youtube. com/watch? $\mathrm{v}=\mathrm{yMUJdMT} 3 \mathrm{YDU}$

Kondakov, Sergey (2012): Ball at Ass (online): http://www.youtube.com/watc $\mathrm{h} ? \mathrm{v}=\mathrm{cu} 2 \mathrm{LulPnBuU} \& \mathrm{list}=\mathrm{PLD} 91 \mathrm{CABFC} 2 \mathrm{~A} 558 \mathrm{BC} 0$

Ladygina-Kohts, Nadezhda (1935): Infant Ape and Human Child (Instincts, Emotions, Play, Habits). Moscow, State Darwin Museum Press, Vol. I, 592. 
Leca, Jean-Baptiste et al. (2010): Indirect Social Influence in the Maintenance of the Stone-Handling Tradition in Japanese Macaques, Macaca fuscata. In: Animal Behaviour, 79, 117-126.

McGrew, William Clement (1993): Chimpanzee Material Culture: Implications for Human Evolution. Cambridge, Cambridge University Press.

McGrew, William Clement et al. (1996): Great Ape Societies. Cambridge, Cambridge University Press.

Mercander, Julio et al. (2002). Excavation of a Chimpanzee Stone Tool Site in the African Rainforest. In: Science, 296, 1452-1455.

Richterová, Dana (2012): Umělecké dílo (online): http://www.youtube.com/ watch?v=irmRVgjRnPQ

Sample, Ian (2009): Chimp who Threw Stones at Zoo Visitors Showed Human Trait, Says Scientist (online): https://www.theguardian.com/science/2009/mar/09/chimp-zoo-stones-science

Soukup, Martin - Bláha, Jan Daniel (2015). Sociokulturní jev „kula“ v Melanésii. In: Geografické rozhledy, 24, 2/14-15: 26-27.

Van Schaik, Karel (2012): Orangutan Cultures (online): http://www.aim.uzh. ch/Research/orangutannetwork/CultureList.html

\section{AUTHORS}

Vančatová Marina, Mgr., PhD., (15. 8. 1958, Perm, Russia). She is well recognized primatologist and ethologist namely with respect to ape and monkey behavior and biology, President of Green Pilgrims non-profit civic association. She is regularly publishing scientific papers in peer reviewed journals and proceedings. She is also very active in popularization of ethological research.

Vančata Václav, doc. RNDr. CSc., (22. 6. 1952, Praha) very well recognized specialist in evolutionary anthropology, paleoanthropology and primatology. He published more than 150 peer reviewed scientific papers on hominid evolution, primate ontogeny and evolution of hominid body size and locomotion. He is associated professor at Department of Biology of Faculty of Education, Charles University Prague, and Department of Anthropology, Faculty of Science, Masaryk University Brno. 
